\title{
Research on the Sustainable Development of Mining Industry OHSAS18001 Based on IFE and EFE Matrix
}

\author{
Jiangdong Bao, Jan Johansson, and Jingdong Zhang
}

\begin{abstract}
The sustainable development of mining occupational health and safety management system is inseparable from its internal and external environment. Through IFE and EFE matrix models, the key internal and external factors affecting the sustainable development of some mining in the Southwest of the Hubei Province are analyzed. Then entropy method is adopted to determine the weight of each key factor. According to the weighted total score ranking, the most important internal and external key factors affecting China's sustainable development include the following: not enough detailed degree of hazard identification, not enough safety awareness, lack of contingency plans to assess the timely exercise, not enough deep mining of internal audit, impact of relevant laws and regulations on enterprises, impact of the interested parties on the changing requirements of the enterprise, risk management brought by interested parties, risk management of product life cycle, and changes in the market environment for enterprises to put forward new requirements. In this paper, combined with OHSAS18001 operation condition of the mining in the Southwest of Hubei Province, seven suggestions for improvement are put forward which provide valuable reference for the sustainable development of mining OHSAS18001.
\end{abstract}

Index Terms-OHSAS18001, sustainable development, IFE and EFE Matrix, entropy method.

\section{INTRODUCTION}

Occupational health and safety management system (OSHAS18001) [1] was a modern safety production management standard in the late 1980s in the world. It is known as the post industrial era of effective management methods just as ISO9001 quality management system and ISO14001 environmental management system. OSHAS18001 takes the system theory as the guide, establishing the procedural and institutional management, identifying the hazard and risk assessment, setting up the corresponding target plan, building personnel ability confirmation and training system and identifying and evaluating the laws and regulations and other requirements for the development of enterprises with the model of Plan-Do-Check-Act (PDCA)[2]. The aim of OHSAS18001 is to achieve continuous improvement of management system,

Manuscript received December 7, 2016; revised March 1, 2017.

Jiangdong Bao and Jan Johansson are with Centre of Advanced Mining and Metallurgy, CAMM, Department of Human Work Science, Luleå University of Technology, Luleå 97751, Sweden (e-mail: bao.jiangdong@1tu.se, Jan.Johansson@1tu.se).

Jingdong Zhang is with Research Center for Environment and Health, Zhongnan University of Economics and Law, Wuhan, 430000, China, corresponding author: Jingdong Zhang (e-mail: 17099337648@163.com). to continuously promote the enterprise to comply with laws and regulations and other requirements, to protect the health and safety of employees and to promote green healthy and sustainable development of enterprises [3].

The acceleration of China's economic development and economic restructuring will have a huge impact on the "Green Barrier", that is, occupational health and safety management system in the international trade. At the same time, our country has accelerated the pace of occupational safety and health legislation, more and more strict requirements on the safety production of enterprises and a large number of safety regulations are introduced. Especially in July 2016, the "occupational disease prevention law" [4] was revised which put forward mandatory regulatory requirements and standards for safety and health. "People oriented and pay attention to employee health and safety" has increasingly become an important symbol and a good image of modern enterprises, which is also the focus of the occupational health and safety management system.

Some common problems including not enough detailed degree of hazard identification, not enough safety awareness and risk management brought by interested parties, etc. were always found during the auditing of hundreds of companies by the author of this paper. Therefore, the entropy method [5] is adopted to carry out the IEF and EFE matrix [6] empirical analysis on the standard terms of OSHSAS18001 with the mining of Southwest of Hubei Province as an example which will explore the healthy development of OHSAS18001 in our country.

\section{STATUS ANALYSIS OF OHSAS18001 OPERATION IN THE MINING OF SOUTHWEST HUBEI}

\section{A. Safety Investment, Loss and Benefit Analysis}

OHSAS18001 operation involves safety technical measures, industrial hygiene measures, safety management and training, labor protection supplies etc. According to the summary of the mining in the Southwest of Hubei Province, the total safety investments from2011 to 2015 were 2.884 million RMB, 3.326 million RMB,3.015 million RMB,3.788 million RMB and 3.972 million RMB ; The total safety losses were 0.893 million RMB,0.904 million RMB, 0.875 million RMB,0.983 million RMB and 0.953 million RMB ; Total production investments were 8.673 million RMB, 8.743 million RMB,7.697 million RMB,8.901 million RMB and 8.904 million $\mathrm{RMB}$ and total safety benefits were 1.235 million RMB,1.4721 million RMB,1.2615 million RMB,1.8056 million RMB and 2.1365 million RMB as shown in Fig.1. 


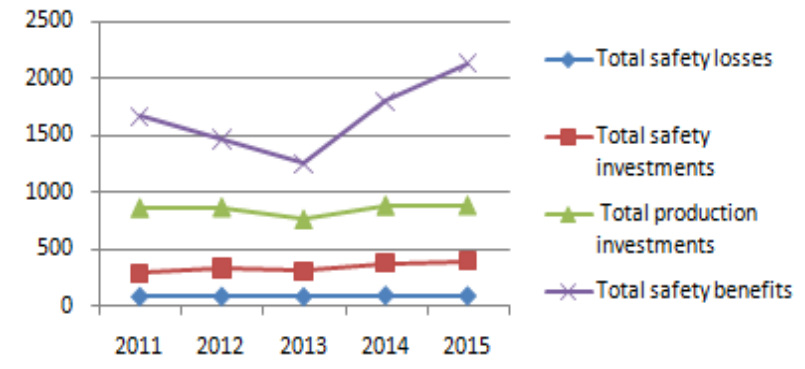

Fig.1. Safety investments, losses and benefits.

From the enterprise data and Fig.1, it can be analyzed that the total safety investment has not changed much, showing a gradual slow growth trend, the total safety loss has not been stable as well as the total safety benefit in the first three years, while it has showed a rising trend in the last two years. All the results make it clear that the safety management of the mining is passive and OHSAS18001 doesn't runs smoothly.

\section{B. Analysis of Interested Parties and External Invironment}

In accordance with the definition of OHSAS18001 standardization, interested parties include suppliers, customers, residents, shareholders, government departments, etc. According to the statistical data of environment and safety management department, from 2011 to 2015 the numbers of residents' complaints were $3,5,7,4$, and 3 . The numbers of patients in occupational disease physical examination were $8,7,8,5$ and 6 . The numbers of corrective action of safety assessment were 9, 8, 11, 10 and 10. The numbers of external relevant laws and regulations and other requirements were 132, 132, 135, 135, 135 and 135 and the numbers of risk sources from suppliers, customers and other risk management were 0, 0, 20, 20, and 20 as shown in Fig. 2.

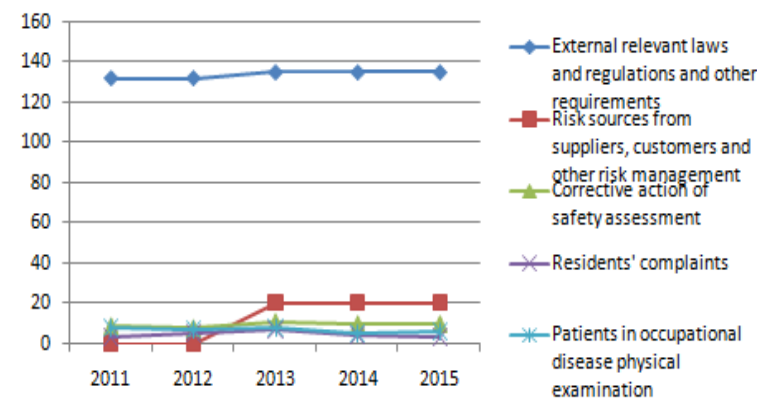

Fig. 2. Statistics of external laws and regulations, risk sources, correction action, complaints and patients in occupational disease physical examination.

From the enterprise data and Fig. 2, the numbers of residents' complaints, patients with occupational disease physical examination and corrective action of safety assessment showed a small wave of instability from 2011 to 2015. The numbers of risk sources from suppliers, customers and other risk management kept zero in the first two years and stayed the same in the last three years. Additionally, the numbers of external relevant laws and regulations and other requirements almost had no change in the past five years. But in fact, national and local laws and regulations are added and updated every year. According to the analysis from the enterprise audit experience of the author, the number of laws and regulations and other requirements of a medium-sized enterprise shall be increased by more than 20 . So it can be concluded that OHSAS18001 of the mining keeps in a stagnant state which needs targeted analysis and rectification.

\section{IFE AND EFE MATRIX ANALYSIS OF OHSAS18001 STANDARD TERMS OF SOME MINING IN SOUTHWEST OF HUBEI PROVINCE}

\section{A. The Determination of Internal and External Key Factors and Evaluation Criteria}

IFE (EFE) is the internal (external) key factor affecting the development of a specific unit.IFE and EFE matrix is a tool for the comprehensive evaluation and analysis of the internal advantages and disadvantages, and the external opportunities and threats faced with the development of a specific unit. IFE (EFE) matrix analysis of the mining in Southwest of Hubei Province is the evaluation way of the internal strengthes (external opportunities) and weaknesses (external threats).In this study, 5 senior staff as well as 1 auditor and 4 experts are invited to conduct interviews and questionnaires, to determine the final 64 internal key factors (which contains 30 strengthes and 34 weaknesses as shown in Table 1) and 21 external key factors (which contains 8 opportunities and 13 threats as shown in Table 2) after layers of screening, and to score the key factors using the expert scoring method[7-8]. According to the reaction degree of the internal and external key factors, each key factor is scored by the score criterion as shown follows: $1=$ not important, $2=$ general important, 3=more important, 4=particularly important[9].

\section{B. Determination of Weight [1]}

The entropy method is used to determine the weight of each key factor, and the steps are as follows:

Step1. Standardization of the data. Standardize the score of internal and external key factors $\mathrm{X}_{1}, \mathrm{X}_{2}, \ldots \mathrm{X}_{\mathrm{i}}(\mathrm{i}=1,2,3, \ldots \mathrm{n})$ affecting the development of OHSAS18001, the value is as follows:

$$
X_{1 i}^{*}=\frac{X_{1 i}-\min \left(X_{i}\right)}{\max \left(X_{i}\right)-\min \left(X_{i}\right)}(i=1,2,3, \ldots n) .
$$

Step 2. Information entropy of key factors. According to the definition of information entropy in information theory, the information entropy is as follows:

$$
\begin{aligned}
& E_{i}=-\ln (n)^{-1} \sum_{i=1}^{n} P_{j i} \ln P_{j i} \text {, where } P_{j i}=\frac{X_{i}^{*}}{\sum^{n} X_{i}^{*}} ; \\
& \text { If } P_{i}=0 \text {, then } \lim _{P_{i} \rightarrow 0} P_{j i} \ln P_{j i}=0
\end{aligned}
$$

Step 3. Determination of the weight of the key factors.

After getting the information entropy of the internal key of $n$ item, suppose the information entropy of the internal key of $n$ item are $E_{1}, E_{2}, \ldots E_{k}$, then the weight of the key factors can be calculated as follows:

$$
W_{i}=\frac{1-E_{i}}{k-\sum_{i=1}^{n} E_{i}}, \text { where } i=1,2,3, \ldots k
$$


TABLE I: IFE MATRIX ANALYSIS FACtORS TABLE

\begin{tabular}{ll}
\hline Standard terms & \\
\hline 4.3.1Planning for hazard & $\mathrm{X}$ \\
identification, risk assessment and & i \\
\hline risk control & $\mathrm{X}_{2}$ \\
\hline & $\mathrm{X}$
\end{tabular}

4.4.1 Resources, roles,
responsibility, accountability and
authority

4.4.2 Competence, training and awareness

4.4.3 Communication,
participation and consultation

4.4.4 Documentation

4.4.5 Document and data control

The programming of document and data control

$\mathrm{X}_{14}$ Clear operational control scheme

$\mathrm{X}_{15}$ The inclusion in management scope of interested parties

4.4.6 Operational control

$\mathrm{X}_{16}$ The inclusion in management scope of change management

$\mathrm{X}_{1}$ The establishment of basic framework of hazard identification system

hazard identification

$\mathrm{X}_{3}$ The determination of objectives of occupational health

and safety which can be measured

$\mathrm{X}_{4}$ Periodic inspection of the objectives and program which promotes the effective operation of the system $\mathrm{X}_{5}$ Regular review of the objectives and program which promotes the effective operation of the system

$\mathrm{X}_{6}$ The programming of access to resources

$\mathrm{X}_{7}$ The programming of accountability and authority

$\mathrm{X}_{8}$ Timely assessment of the ability of personnel

$\mathrm{X}_{9}$ Timely sub level training and plan

$\mathrm{X}_{10}$ The establishment of internal communication

$\mathrm{X}_{12}$ The establishment of a document management channels

management

$\mathrm{X}_{17}$ The development of more complete emergency plan

4.4.7 Emergency preparedness and $\quad \mathrm{X}_{18}$ The identification of fire and chemical emergency response plan

$\mathrm{X}_{19}$ Regular emergency drills for fire and chemicals

$\mathrm{X}_{20}$ The establishment of objectives monitoring

4.5.1 Performance measurement and monitoring

$\mathrm{X}_{21}$ The establishment of proactive and reactive measures of performance

$\mathrm{X}_{22}$ The results record of the measurement

4.5.2 Evaluation of compliance

$\mathrm{X}_{23}$ The determination of the scope and requirements of the periodic evaluation

$\mathrm{X}_{24}$ The establishment of the method of the incident investigation.

4.5.3 Incident investigation, nonconformity, corrective action and preventive action

$\mathrm{X}_{25}$ The establishment of the steps to take corrective action.

$\mathrm{X}_{26}$ The establishment of the steps to take preventive action.

\subsubsection{Objectives and program}

Internal key factors: Weaknesses

$\mathrm{X}_{31}$ Not enough detailed degree of hazard identification

$\mathrm{X}_{32}$ Not updated in time

$\mathrm{X}_{33}$ Not enough coverage level of the objectives

$\mathrm{X}_{34}$ Not enough cost and benefit analysis of the program

$\mathrm{X}_{35}$ Not very effective program

$\mathrm{X}_{36}$ Not enough rational resources investment

$\mathrm{X}_{37}$ Not enough coverage level of the accountability and authority

$\mathrm{X}_{38}$ Passive training

$\mathrm{X}_{39}$ Not enough safety awareness

$\mathrm{X}_{40}$ Poor internal communication

$\mathrm{X}_{42}$ Too many documents in terms of effectiveness and efficiency.

$\mathrm{X}_{43}$ Not enough update documents

$\mathrm{X}_{44}$ Not enough control executive power

$\mathrm{X}_{45}$ The ignorance of management responsibilities of the interested parties

$\mathrm{X}_{46}$ Not clear operational guidelines

$\mathrm{X}_{47}$ The lack of concept and technology of engineering technology control

$\mathrm{X}_{48}$ Lack of effectiveness of emergency plan

$\mathrm{X}_{49}$ Not comprehensive emergency plan

$\mathrm{X}_{50}$ Lack of contingency plans to assess the timely exercise

$\mathrm{X}_{51}$ Not reflected the true performance of the objectives monitoring

$\mathrm{X}_{52}$ Lack of monitoring and analysis of incidents and near misses in the detection of passivity

$\mathrm{X}_{53}$ Not processed results of measurement according to the PDCA principle

$\mathrm{X}_{54}$ Not enough periodic evaluation of other requirements

$\mathrm{X}_{55}$ Not clear scope and extent of the incident investigation

$\mathrm{X}_{56}$ Not enough event statistical analysis method

$\mathrm{X}_{57}$ Not formed a closed loop of corrective action

$\mathrm{X}_{58}$ Not evaluated effectiveness of corrective and preventive actions

\begin{tabular}{ll}
\hline 4.5.4Control of records & $\mathrm{X}_{27}$ Clear record requirements \\
\hline 4.5.5Internal audit & $\mathrm{X}_{28}$ Clear purpose and procedures of internal audit \\
\hline & \\
\hline & $\mathrm{X}_{29}$ Clear input requirements of management review \\
& $\mathrm{X}_{30}$ Clear output requirements of management review
\end{tabular}

$\mathrm{X}_{59}$ Not enough traceability of records

$\mathrm{X}_{60}$ Not enough internal auditor ability

$\mathrm{X}_{61}$ Not enough deep mining of internal audit

$\mathrm{X}_{62}$ Not enough effectiveness of management review

$\mathrm{X}_{63}$ Not enough support for the system from the top management

$\mathrm{X}_{64}$ Not aware of the system from the top management

TABLE II: EFE MATRIX ANALYSIS FACTORS TABLE

\begin{tabular}{ll}
\hline \hline Standard terms & External key factors: Opportunities \\
\hline $\begin{array}{l}\text { 4.3.2 Legal and other } \\
\text { requirements }\end{array}$ & $\begin{array}{l}\mathrm{U}_{1} \text { The escort for enterprise development from relevant } \\
\text { laws and regulations of local and national health and safety }\end{array}$
\end{tabular}
External key factors: Threats

$\mathrm{U}_{9}$ Less capital investment on relevant laws and regulations

$\mathrm{U}_{10}$ Impact of relevant laws and regulations on enterprises 
$\mathrm{U}_{11}$ Impact of relevant laws and regulations on other requirements

$\mathrm{U}_{12}$ Impact of up-to-date relevant laws and regulations on enterprises

4.4.3 Communication, $\quad \mathrm{U}_{2}$ The establishment of channels of consultation with participation and consultation
$\mathrm{U}_{13}$ Too single a communication between the interested parties and enterprises
$\mathrm{U}_{3} \mathrm{~A}$ fixed communication between the interested parties and enterprises

$\mathrm{U}_{14}$ Impact of the interested parties on the changing requirements of the enterprise

$\mathrm{U}_{15}$ Conflict of interest between interested parties and enterprises

$\mathrm{U}_{16}$ Risk management brought by interested parties

$\mathrm{U}_{17}$ Risk management of product life cycle

\begin{tabular}{ll}
\hline 4.1General requirements & $\mathrm{U}_{4}$ Vitality of enterprises brought by the market economy \\
\hline & $\mathrm{U}_{5}$ OHSAS18001 certificate of global passport \\
& $\mathrm{U}_{6}$ The increase of business orders \\
& $\mathrm{U}_{7}$ The cancellation of second party audit \\
& $\mathrm{U}_{8}$ More smooth and corporate Communication between \\
interested parties and enterprises
\end{tabular}

$\mathrm{U}_{18}$ Changes in the market environment for enterprises to put forward new requirements.

$\mathrm{U}_{19}$ The form of a crisis of confidence from the interested parties to enterprises with the health and safety issues of the product

$\mathrm{U}_{20}$ A crisis of confidence of the enterprise certificate
from the interested parties to enterprises with accidents in
enterprises
$\mathrm{U}_{21}$ The elimination of the enterprise from the market due
to certificate failure

\section{IFE and EFE Matrix Analysis}

According to the formula (1), (2) and (3), the weights of strengthes, weaknesses, opportunities, and threats of the internal and external key factors can be calculated, whose sum equals 1. And according to the scoring criteria, evaluation number of people can be listed. The weight is multiplied by the total score to get the weighted total score which is used to analyze and evaluate the standard terms as shown in Table III and Table IV.

TABLE III: SUMMARY TABLE OF IFE MATRIX ANALYSIS

\begin{tabular}{|c|c|c|c|c|c|c|c|c|c|c|c|c|c|c|c|c|}
\hline $\begin{array}{l}\text { Standard } \\
\text { terms }\end{array}$ & $\begin{array}{l}\text { Streng } \\
\text { thes }\end{array}$ & 1 & 2 & 3 & 4 & $\begin{array}{l}\text { Total } \\
\text { score }\end{array}$ & Weight & $\begin{array}{l}\text { Weighted } \\
\text { total } \\
\text { score }\end{array}$ & $\begin{array}{l}\text { Weaknes } \\
\text { ses }\end{array}$ & 1 & 2 & 3 & 4 & $\begin{array}{l}\text { Total } \\
\text { score }\end{array}$ & Weight & $\begin{array}{l}\text { Weighted } \\
\text { total } \\
\text { score }\end{array}$ \\
\hline \multirow{2}{*}{4.3 .1} & $\mathrm{X}_{1}$ & 1 & 1 & 4 & 4 & 31 & 0.0172 & 0.5327 & $\mathrm{X}_{31}$ & 1 & 1 & 1 & 7 & 34 & 0.0397 & 1.3514 \\
\hline & $\mathrm{X}_{2}$ & 1 & 2 & 3 & 4 & 30 & 0.0095 & 0.2847 & $\mathrm{X}_{32}$ & 1 & 1 & 3 & 5 & 32 & 0.0194 & 0.6220 \\
\hline \multirow{3}{*}{4.3 .3} & $\mathrm{X}_{3}$ & 2 & 1 & 3 & 4 & 29 & 0.0095 & 0.2752 & $\mathrm{X}_{33}$ & 1 & 2 & 2 & 5 & 31 & 0.0148 & 0.4579 \\
\hline & $\mathrm{X}_{4}$ & 2 & 3 & 2 & 3 & 26 & 0.0018 & 0.0467 & $\mathrm{X}_{34}$ & 2 & 1 & 1 & 6 & 31 & 0.0265 & 0.8219 \\
\hline & $\mathrm{X}_{5}$ & 2 & 3 & 1 & 4 & 27 & 0.0095 & 0.2562 & $\mathrm{X}_{35}$ & 1 & 2 & 1 & 6 & 32 & 0.0265 & 0.8484 \\
\hline \multirow{2}{*}{4.4 .1} & $\mathrm{X}_{6}$ & 2 & 2 & 3 & 3 & 27 & 0.0018 & 0.0485 & $\mathrm{X}_{36}$ & 1 & 2 & 2 & 5 & 31 & 0.0148 & 0.4579 \\
\hline & $\mathrm{X}_{7}$ & 1 & 2 & 3 & 4 & 30 & 0.0095 & 0.2847 & $X_{37}$ & 1 & 1 & 2 & 6 & 33 & 0.0265 & 0.8749 \\
\hline \multirow{2}{*}{4.4 .2} & $\mathrm{X}_{8}$ & 3 & 2 & 2 & 3 & 25 & 0.0018 & 0.0449 & $\mathrm{X}_{38}$ & 1 & 2 & 1 & 6 & 32 & 0.0265 & 0.8484 \\
\hline & $\mathrm{X}_{9}$ & 1 & 2 & 4 & 3 & 29 & 0.0095 & 0.2752 & $\mathrm{X}_{39}$ & 1 & 1 & 1 & 7 & 34 & 0.0397 & 1.3514 \\
\hline \multirow{2}{*}{4.4 .3} & $\mathrm{X}_{10}$ & 2 & 1 & 3 & 4 & 29 & 0.0095 & 0.2752 & $\mathrm{X}_{40}$ & 1 & 1 & 3 & 5 & 32 & 0.0194 & 0.6220 \\
\hline & $\mathrm{X}_{11}$ & 2 & 2 & 2 & 4 & 28 & 0.0048 & 0.1351 & $\mathrm{X}_{41}$ & 1 & 2 & 1 & 6 & 32 & 0.0265 & 0.8484 \\
\hline 4.4 .4 & $\mathrm{X}_{12}$ & 2 & 2 & 2 & 4 & 28 & 0.0048 & 0.1351 & $\mathrm{X}_{42}$ & 1 & 1 & 2 & 6 & 33 & 0.0265 & 0.8749 \\
\hline 4.4 .5 & $\mathrm{X}_{13}$ & 2 & 2 & 3 & 3 & 27 & 0.0018 & 0.0485 & $\mathrm{X}_{43}$ & 1 & 2 & 2 & 5 & 31 & 0.0148 & 0.4579 \\
\hline \multirow{4}{*}{4.4 .6} & $\mathrm{X}_{14}$ & 2 & 2 & 2 & 4 & 28 & 0.0048 & 0.1351 & $\mathrm{X}_{44}$ & 1 & 1 & 2 & 6 & 33 & 0.0265 & 0.8749 \\
\hline & $\mathrm{X}_{15}$ & 2 & 2 & 3 & 3 & 27 & 0.0018 & 0.0485 & $\mathrm{X}_{45}$ & 1 & 1 & 3 & 5 & 32 & 0.0194 & 0.6220 \\
\hline & $\mathrm{X}_{16}$ & 1 & 2 & 3 & 4 & 30 & 0.0095 & 0.2847 & $\mathrm{X}_{46}$ & 1 & 2 & 2 & 5 & 31 & 0.0148 & 0.4579 \\
\hline & & & & & & & & & $\mathrm{X}_{47}$ & 2 & 1 & 1 & 6 & 31 & 0.0265 & 0.8219 \\
\hline \multirow{3}{*}{4.4 .7} & $\mathrm{X}_{17}$ & 2 & 2 & 3 & 3 & 27 & 0.0018 & 0.0485 & $\mathrm{X}_{48}$ & 1 & 1 & 3 & 5 & 32 & 0.0194 & 0.6220 \\
\hline & $\mathrm{X}_{18}$ & 1 & 4 & 2 & 3 & 27 & 0.0095 & 0.2562 & $\mathrm{X}_{49}$ & 1 & 1 & 2 & 6 & 33 & 0.0265 & 0.8749 \\
\hline & $\mathrm{X}_{19}$ & 3 & 2 & 2 & 3 & 25 & 0.0018 & 0.0449 & $\mathrm{X}_{50}$ & 1 & 1 & 1 & 7 & 34 & 0.0397 & 1.3514 \\
\hline \multirow{3}{*}{4.5 .1} & $\mathrm{X}_{20}$ & 3 & 3 & 2 & 2 & 23 & 0.0018 & 0.0413 & $\mathrm{X}_{51}$ & 3 & 1 & 1 & 5 & 28 & 0.0194 & 0.5442 \\
\hline & $\mathrm{X}_{21}$ & 2 & 1 & 3 & 4 & 29 & 0.0095 & 0.2752 & $\mathrm{X}_{52}$ & 1 & 1 & 4 & 4 & 31 & 0.0172 & 0.5327 \\
\hline & $X_{22}$ & 3 & 2 & 2 & 3 & 25 & 0.0018 & 0.0449 & $\mathrm{X}_{53}$ & 1 & 1 & 2 & 6 & 33 & 0.0265 & 0.8749 \\
\hline 4.5 .2 & $\mathrm{X}_{23}$ & 1 & 2 & 2 & 5 & 31 & 0.0148 & 0.4579 & $\mathrm{X}_{54}$ & 1 & 2 & 2 & 5 & 31 & 0.0148 & 0.4579 \\
\hline 4.5 .3 & $\mathrm{X}_{24}$ & 2 & 3 & 3 & 2 & 25 & 0.0018 & 0.0449 & $\mathrm{X}_{55}$ & 2 & 1 & 2 & 5 & 30 & 0.0148 & 0.4431 \\
\hline
\end{tabular}




\begin{tabular}{lllllllllllllllll} 
& $\mathrm{X}_{25}$ & 3 & 2 & 2 & 3 & 25 & 0.0018 & 0.0449 & $\mathrm{X}_{56}$ & 1 & 1 & 3 & 5 & 32 & 0.0194 & 0.6220 \\
& $\mathrm{X}_{26}$ & 2 & 1 & 3 & 4 & 29 & 0.0095 & 0.2752 & $\mathrm{X}_{57}$ & 2 & 1 & 1 & 6 & 31 & 0.0265 & 0.8219 \\
& & & & & & & & & $\mathrm{X}_{58}$ & 1 & 1 & 3 & 5 & 32 & 0.0194 & 0.6220 \\
\hline 4.5 .4 & $\mathrm{X}_{27}$ & 3 & 2 & 2 & 3 & 25 & 0.0018 & 0.0449 & $\mathrm{X}_{59}$ & 1 & 1 & 2 & 6 & 33 & 0.0265 & 0.8749 \\
\hline \multirow{2}{*}{4.5 .5} & $\mathrm{X}_{28}$ & 3 & 2 & 1 & 4 & 26 & 0.0095 & 0.2467 & $\mathrm{X}_{60}$ & 1 & 2 & 1 & 6 & 32 & 0.0265 & 0.8484 \\
& & & & & & & & & $\mathrm{X}_{61}$ & 1 & 1 & 1 & 7 & 34 & 0.0397 & 1.3514 \\
\hline \multirow{3}{*}{4.6} & $\mathrm{X}_{29}$ & 1 & 1 & 4 & 4 & 31 & 0.0172 & 0.5327 & $\mathrm{X}_{62}$ & 1 & 1 & 2 & 6 & 33 & 0.0265 & 0.8749 \\
& $\mathrm{X}_{30}$ & 1 & 2 & 3 & 4 & 30 & 0.0095 & 0.2847 & $\mathrm{X}_{63}$ & 1 & 3 & 2 & 4 & 29 & 0.0095 & 0.2752 \\
& & & & & & & & 5.7535 & $\mathrm{X}_{64}$ & 3 & 1 & 1 & 5 & 28 & 0.0194 & 0.5442 \\
\hline \hline
\end{tabular}

TABLE IV: SUMMARY TABLE OF EFE MATRIX ANALYSIS

\begin{tabular}{|c|c|c|c|c|c|c|c|c|c|c|c|c|c|c|c|c|}
\hline $\begin{array}{l}\text { Standard } \\
\text { terms }\end{array}$ & Strengthes & 1 & 2 & 3 & 4 & $\begin{array}{l}\text { Total } \\
\text { score }\end{array}$ & Weight & $\begin{array}{l}\text { Weighted } \\
\text { total } \\
\text { score }\end{array}$ & Weaknesses & 1 & 2 & 3 & 4 & $\begin{array}{l}\text { Total } \\
\text { score }\end{array}$ & Weight & $\begin{array}{l}\text { Weighted } \\
\text { total } \\
\text { score }\end{array}$ \\
\hline \multirow{4}{*}{4.3 .2} & $\mathrm{U}_{1}$ & 1 & 1 & 3 & 5 & 32 & 0.0406 & 1.3000 & $\mathrm{U}_{9}$ & 2 & 1 & 1 & 6 & 31 & 0.0554 & 1.7180 \\
\hline & & & & & & & & & $\mathrm{U}_{10}$ & 1 & 1 & 1 & 7 & 34 & 0.0831 & 2.8250 \\
\hline & & & & & & & & & $\mathrm{U}_{11}$ & 1 & 1 & 4 & 4 & 31 & 0.0359 & 1.1140 \\
\hline & & & & & & & & & $\mathrm{U}_{12}$ & 1 & 2 & 2 & 5 & 31 & 0.0309 & 0.9570 \\
\hline 4.4 .3 & $\mathrm{U}_{2}$ & 3 & 1 & 3 & 3 & 27 & 0.0135 & 0.3650 & $\mathrm{U}_{13}$ & 2 & 1 & 1 & 6 & 31 & 0.0554 & 1.7180 \\
\hline \multirow{4}{*}{4.4 .6} & $\mathrm{U}_{3}$ & 1 & 2 & 3 & 4 & 29 & 0.0198 & 0.5750 & $\mathrm{U}_{14}$ & 1 & 1 & 1 & 7 & 34 & 0.0831 & 2.8250 \\
\hline & & & & & & & & & $\mathrm{U}_{15}$ & 1 & 2 & 2 & 5 & 31 & 0.0309 & 0.9570 \\
\hline & & & & & & & & & $\mathrm{U}_{16}$ & 1 & 1 & 1 & 7 & 34 & 0.0831 & 2.8250 \\
\hline & & & & & & & & & $\mathrm{U}_{17}$ & 1 & 1 & 1 & 7 & 34 & 0.0831 & 2.8250 \\
\hline 4.1 & $\mathrm{U}_{4}$ & 1 & 3 & 4 & 2 & 26 & 0.0198 & 0.5160 & $\mathrm{U}_{18}$ & 1 & 1 & 1 & 7 & 34 & 0.0831 & 2.8250 \\
\hline \multirow{4}{*}{$\begin{array}{l}\text { External } \\
\text { audit }\end{array}$} & $\mathrm{U}_{5}$ & 2 & 3 & 3 & 2 & 29 & 0.0038 & 0.1090 & $\mathrm{U}_{19}$ & 1 & 2 & 1 & 6 & 32 & 0.0554 & 1.7740 \\
\hline & $\mathrm{U}_{6}$ & 1 & 2 & 1 & 6 & 31 & 0.0554 & 1.7180 & $\mathrm{U}_{20}$ & 1 & 2 & 1 & 6 & 32 & 0.0554 & 1.7740 \\
\hline & $\mathrm{U}_{7}$ & 1 & 1 & 3 & 5 & 31 & 0.0406 & 1.2600 & $\mathrm{U}_{21}$ & 3 & 1 & 1 & 5 & 28 & 0.0406 & 1.1380 \\
\hline & $\mathrm{U}_{8}$ & 2 & 1 & 2 & 5 & 30 & 0.0309 & 0.9260 & & & & & & & & \\
\hline
\end{tabular}

\section{RESUlts}

\section{A. The Results of IFE Internal Strengthes and Weaknesses}

It can be concluded from Tab.3 that the weighted total score of internal weaknesses is 25.751 which is nearly 5 times as much as the one of internal strengthes. Additionally, the weighted total score of more than 1 point in the 64 terms of the key factors of the most impact on the development of OHSAS18001 as follows: $\mathrm{X}_{31}$ Not enough detailed degree of hazard identification, $\mathrm{X}_{39}$ Not enough safety awareness, $\mathrm{X}_{50}$ Lack of contingency plans to assess the timely exercise and $\mathrm{X}_{61}$ Not enough deep mining of internal audit.

\section{B. The Results of EFE External Opportunities and Threats}

It can be concluded from Tab.4 that the weighted total score of external threats is 25.276 which is 4 times as much as the one of external opportunities. Additionally, the weighted total score of more than 2 point in the 21 terms of the key factors of the most impact on the development of OHSAS18001 as follows: $\mathrm{U}_{10}$ Impact of relevant laws and regulations on enterprises, $\mathrm{U}_{14}$ Impact of the interested parties on the changing requirements of the enterprise, $U_{16}$ Risk management brought by interested parties, $\mathrm{U}_{17}$ Risk management of product life cycle and $\mathrm{U}_{18}$ Changes in the market environment for enterprises to put forward new requirements.

\section{SUGGESTIONS}

According to the current operation status of the mining OHSAS18001 together with the analysis results of internal and external matrix, 7 suggestions are put forward for the sustainable and healthy development of the mining 18001 as follows:

\section{A. Understanding the Leading Role and People Oriented} Training [3]

It can be concluded from Tab.3 that the direct reason for not enough safety awareness is the lack of safety and training which needs relevant financial support. That is to say, it is closed related to the leadership. The direct reason for not enough deep mining of internal audit is the lack of enough ability for internal auditor which needs to be trained and also to be thought highly of by the leader. Leading role is a prerequisite, while safety training is an enhancement.

\section{B. Understanding the Perfect Planning [3]}

It can be concluded from Tab.3 that not enough detailed degree of hazard identification results from the lack of planning. According to the requirements of OHSAS18001, 4.3.1Planning for hazard identification, risk assessment and risk control is the core element of the system, which is closed related to 4.3.2 Legal and other requirements, 4.3.3 Objectives and program, 4.4.6 Operational control, 4.5.1 Performance measurement and monitoring and 4.6Management review. OHSAS18001 follows the process 
method of Plan-Do-Check-Act (PDCA) cycle which makes the system continuously improved.

\section{Understanding the Periodic Checking and Assessing [3]}

It can be concluded from Tab.3 that the lack of contingency plans to assess the timely exercise results from the lack of understanding the 4.4.7standard terms. According to 4.4 .7 terms, the organization shall establish and maintain plans and procedures to identify the potential for, and responses to, incidents and emergency situations, and for preventing and mitigating the likely illness and injury that may be associated with them. The organization shall review its emergency preparedness and response plans and procedures, in particular after the occurrence of incidents or emergency situations. Additionally, the organization shall also periodically test such procedures where practicable.

\section{Understanding the Legal and other Requirements [3]}

The organization shall establish, implement and maintain a process to:

1) Identify and have access to current legal requirements and other requirements to which the organization subscribes related to its OHSAS risks and OHSAS management system;

2) Determine how to apply and meet these requirements. The organization shall maintain and retain documented information of: legal requirements and other requirements to which the organization subscribes, ensuring this documented information is updated to reflect changes; how compliance with its legal requirements and other requirements to which the organization subscribes will be achieved.

\section{E. Understanding the Organization and its Context [10]}

The organization shall determine external and internal issues that are relevant to its purpose and objectives and that affect its ability to achieve the intended outcome(s) of its OHSAS management system. External and internal issues relate to the business environment in which the organization seeks to achieve its objectives (reference to "business" in this International Standard can be interpreted broadly to mean those activities that are core to the purposes of the organization's existence).

\section{F. Understanding the Needs and Expectations of Interested Parties [10]}

The organization shall determine:

1) The interested parties that are relevant to the OHSAS 18001;

2) The relevant requirements of these interested parties, and which of these become applicable legal and other requirements to which the organization subscribes.

\section{G. Assessment of OHSAS Risks [10]}

The organization shall establish, implement and maintain a process to:

1) Assess and prioritize OHSAS risk;

2) Identify opportunities to lower OHSAS risk;

3) Determine controls, taking into account legal requirements and other requirements and considering the hierarchy of controls;
4) Maintain and keep current, documented information on its assessment of OHSAS risks, methodology(ies) used, outcomes of the assessment and controls identified.

The organization shall analyze the underlying causes of incidents and update its assessment of OHSAS risks as necessary.

The organization's methodology(ies) for assessment of risk shall be defined with respect to its scope, nature and timing, to ensure it is proactive rather than reactive and used in a systematic way.

\section{CONCLUSIONS}

U6 The increase of business orders of EFE external analysis result ranked first in the external key factors, from which it can be concluded that the mining industry attaches more importance to the economic benefits than people-oriented management. While U14 Impact of the interested parties on the changing requirements of the enterprise, U16 Risk management brought by interested parties, U17 Risk management of product life cycle and U18 Changes in the market environment for enterprises make it clear that the mining industry should pay attention to the internal and external environment of the organization and the related risk management, which is consistent with the requirement of the new edition ISO45001 (DIS) of OHSAS18001.

In this paper, the entropy method is used to refine the OHSAS18001 standard terms into quantitative indicators. The weight of each key factor and weighted score are calculated by the scores from senior staff, auditors and experts. Compared with those subjective valuation methods, the entropy method is of high precision and more objective which can better explain the results, ensures the reliability of the results and provides a direction for diagnosis and improvement of OHSAS18001.

The interested parties, the background of organization, management mode and single system or multi system of different minings in China vary greatly. There are many different ways to evaluate the key factors of OHSAS1801 which also lead to various results. Thus, this method allows for necessary adjustments according to the actual situation and experience when the key factors are chosen and evaluated. For future work, the research in this area should be strengthened, the constructed model should be optimized, and in the selection of evaluation methods, 2-tuple Linguistic Information, Grey Relationa Analysis and AHP, etc. should be effectively integrated to lay the foundation for sustainable green development of mining OHSAS18001.

\section{ACKNOWLEDGMENT}

Authors thank the statistical personnel of the case study area for their cooperation in the study and leaders of the mining for the guidance.

\section{REFERENCES}

[1] General Administration of Quality Supervision, Inspection and Quarantine of People's Republic of China, National Standards of the People's Republic of China, "GB/T28001-2011 Occupational Health and Safety Management Systems Requirements."

[2] S. P. Robbins, Management, Renmin University of China Press, 2012. 
[3] Y.G. Cao., "Analysis on the influencing factors of HSE management system in Enterprises," Safety, vol.02, pp. 34-36, 2009.

[4] Occupational Disease Prevention Law (Hubei Provincial Safety Production Supervision Authority). [Online]. Available: http://www.hubeisafety.gov.cn/ajj_new/shuxingcaidan/articlemore.as p?menuid $=152$ \&menu $1=\% \mathrm{D} 6 \% \mathrm{~B} 0 \% \mathrm{D} 2 \% \mathrm{~B} 5 \% \mathrm{CE} \% \mathrm{C} 0 \% \mathrm{C} 9 \% \mathrm{FA}$

[5] P. Z. Tang, D. Chen, and Y. S. Hou, "Entropy method combined with extreme learning machine method for the short-term photovoltaic power generation forecasting," Chaos, Solitons \& Fractals, vol. 89, pp. 243-248, 2016.

[6] H. Zhao and L. J. Guan, "Research on the sustainable development of higher education in our country based on IFE and EFE matrix," Modern education management, vol. 9, pp. 87-92, 2016.

[7] X. J. Xie, "Quantitative study of SWOT analysis," Science and Technology Information Publishing House, vol.12, pp.133-139, 2009.

[8] Y. D. Li, "Research on the competition strategy of civil aviation company based on SWOT analysis," Shopping mall modernization, vol.05, pp. 136-137, 2008.

[9] Y. Y. Wang and C. M. Kong, "SWOT analysis of human resource strategy based on FEI and EEF matrix - Taking N M aviation ground services Co. Ltd as an example," Economic Forum, vol. 07, pp. 119-123, 2013

[10] ISO/DIS 45001 Occupational health and safety management systems -Requirements with guidance for use. [Online]. Available: $\mathrm{http}: / / \mathrm{www}$. iso.org/iso/catalogue_detail?csnumber=63787

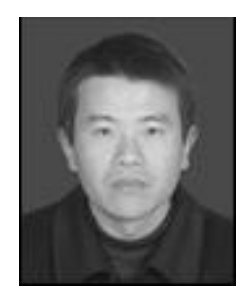

Jiangdong Bao is currently working toward the Ph.D degree at Centre of Advanced Mining and Metallurgy, CAMM, Department of Human Work Science, Luleå University of Technology, and Research Center for Environment and Health, Zhongnan University of Economics and Law for another $\mathrm{Ph} . \mathrm{D}$ degree. His current research interests include Quality, Environment and Occupational Health and Safety Management System (that is, Standardization Engineering).

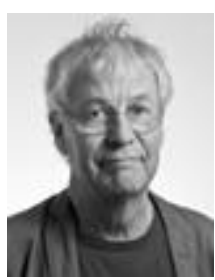

Jan Johansson is a professor of the Department of Business Administration, Technology and Social Sciences, Luleå University of Technology. He is also leading a big division in Industrial Work Environment. His publications achieve more than 200. And his current research interests include Industrial Work Environment, etc.

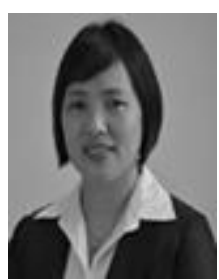

Jingdong Zhang is a head of School of Information and Safety Engineering, Zhongnan University of Economics and Law. Her publications achieve more than 200 as a leading professor. And her current research interests include Environmental Safety Management, Environmental Quality and Safety Assessment, Occupational Health Engineering and Management, etc. 